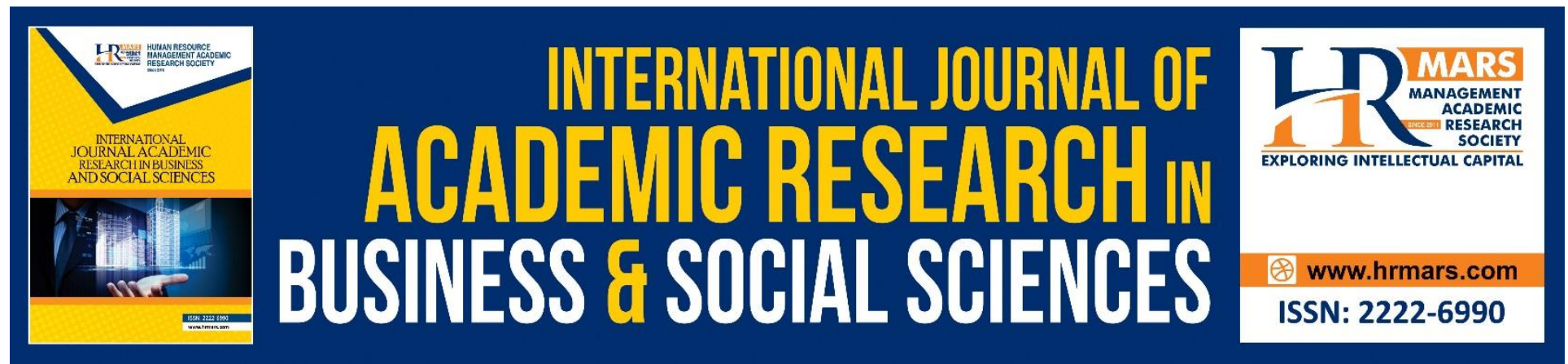

\title{
The Impact of Human Resouce Practises, Leadership Style And Religiousity on Cyber Deviance
}

\author{
Maslina Mansor, Fadzilah Akmal, Normazlina Abu Bakar @ Harun, \\ Norfadzilah Rashid, Rashidah Mohd Ibrahim
}

To Link this Article: http://dx.doi.org/10.6007/IJARBSS/v8-i11/5169 DOI: $10.6007 /$ IJARBSS/v8-i11/5169

Received: 19 Oct 2018, Revised: 26 Nov 2018, Accepted: 02 Dec 2018

Published Online: 04 Dec 2018

In-Text Citation: (Mansor, Akmal, Harun, Rashid, \& Ibrahim, 2018)

To Cite this Article: Mansor, M., Akmal, F., Harun, N. A. B. @, Rashid, N., \& Ibrahim, R. M. (2018). The Impact of Human Resouce Practises, Leadership Style And Religiousity on Cyber Deviance. International Journal of Academic Research in Business and Social Sciences, 8(11), 1283-1293.

Copyright: (c) 2018 The Author(s)

Published by Human Resource Management Academic Research Society (www.hrmars.com)

This article is published under the Creative Commons Attribution (CC BY 4.0) license. Anyone may reproduce, distribute, translate and create derivative works of this article (for both commercial and non-commercial purposes), subject to full attribution to the original publication and authors. The full terms of this license may be seen

at: http://creativecommons.org/licences/by/4.0/legalcode

Vol. 8, No. 11, 2018, Pg. 1283 - 1293

http://hrmars.com/index.php/pages/detail/IJARBSS

JOURNAL HOMEPAGE

Full Terms \& Conditions of access and use can be found at http://hrmars.com/index.php/pages/detail/publication-ethics 


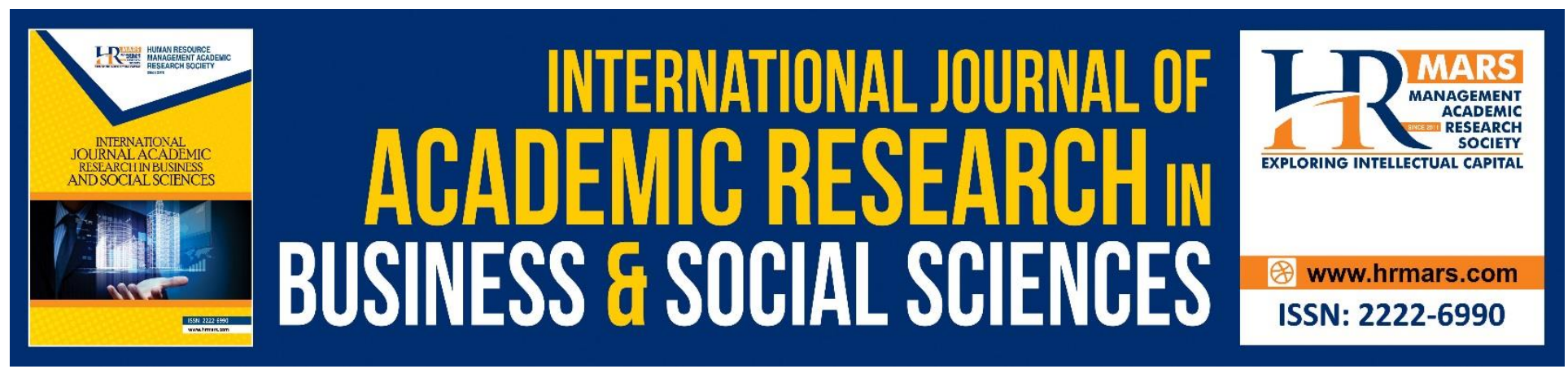

\title{
The Impact Of Human Resouce Practises, Leadership Style And Religiousity On Cyber Deviance
}

\author{
MaslinaMansor, Fadzilah Akmal, Normazlina Abu Bakar @ \\ Harun, Norfadzilah Rashid, Rashidah Mohd Ibrahim \\ Faculty of Economics and Management Sciences, Universiti Sultan Zainal Abidin, 21030 \\ UniSZA, Kuala Nerus, Terengganu, Malaysia
}

\begin{abstract}
:
Deviant behaviour is defined as the employees' personal voluntary effort and behaviour that go against and violate the organizational norms which might threaten the well-beings of individual colleague, productivity of organization, or both. Broad number of researches has affirmed workplace deviance is adverse, offensive and disruptive behaviour that has negative relationship towards individual personnel and organizational well-being. In fact, workplace deviance serve as the challenges for organizational growth. This is a conceptual paper and the the purpose of this paper is to propose a conceptual frameweork and to establish a link between HR practices and Deviant Work Behavior (DWBs). Within this context this paper will also conceptually propose the possibility of Islamic spirituality to moderate this relationship. In this manner the paper will propose a research model and develop propositions to be later tested empirically.

Keywords: Human Resource Practices. Work Deviant Behavior (DWBs) Islamic Spritualitiy.
\end{abstract}

\section{INTRODUCTION}

\section{Background of the Study}

Deviant Work Behavior (DWBs)is quite common among employees in many organizations, but much of it apparently goes overlooked, unreported, or both (Bennett \& Robinson, 2000). Robinson and Bennett (1995) defined deviant workplace behaviors (DWBs), as behaviors that employees exhibit voluntarily, significantly violating organizational norms and putting at risk the well-being of the organization, its members, or both. DWBscan be intentional or unintentional and can result from a wide range of underlying causes and motivations. DWBsis the employees' behavior that goes against the goals of an organization. According to Marcus \& Schuler (2004), all acts of DWBsviolate the legitimate interests of an organization by harming the members of the organization and/or organization as a whole. It involves a wide spectrum of behaviors that harm employees, customers and/or the organization. These behaviors range from severe, 
systematic, and abusive to milder and ambiguous episodes of workplace incivility (Fox \& Spector, 2005). According to Porath, Maclnnes and Folkes (2011), "witnessing incivility among employees is not normal, it is not rare either". Examples of DWBs are: intentionally working slow, taking long breaks, sabotage of equipment, theft of property, showing favoritism, gossiping, sexual harassment, blaming others, verbal abuse, physical abuse, receiving bribe, and being corrupt.

Every year,business organizations persevere financial losses worth billions in US dollars at the handsof their employees through theft, fraud, vandalism, sabotage, voluntary absenteeism,etc. (Lawrence and Robinson, 2007; Chirasha and Mahapa, 2012). It is not only thefinancial outlay but also the social cost that is stressing the majority of organizations.Consequently, the business world in discovering why employees engage in WDBs, in whatway they can be socially responsible and how WD can be harnessed.There is growing interest among researchers and practitioners concerning deviant workplace behaviors in the consequences of these negative behaviors. Research conducted by Meiners (2005) illustrates that organization in the USA losses $6 \%$ of its annual revenues which is almost $\$ 660$ billion annually by only one types of deviant work behavior - theft.

Studies on this issue are steadily increasing with emphasis given on examining the contributing factors. However, upon review of the literatures, little is known of the role of human resource (HR) practices on deviant workplace behaviour, despite the extant evidence on the effect of such practices on shaping employee attitudes and behaviour such as organizational commitment, job satisfaction, and job performance (Faridahwati \&Chandrakantan Subramaniam and Hadziroh, 2011).

The present study is to examine the relationship between HRM practices and WBDs. To this end, HRM practices are viewed in terms of job description, employment security, result-oriented appraisal and planning and internal career opportunity.Organizational settings provide many factors that could influence whether employees decide to engage in these behaviors. Given the dearth of existing research on the role of HR practices in shaping workplace deviance, the present study aimed to explore the issue further.

One possible solution proposed by numerous researchers as a remedies for managing WDBs (Fry, 2003; Reave, 2005;Sulaiman et al., 2013b; Bhatti et al., 2015) is to encourage islamic spirituality. Researchsupports that spirituality tends to motivate employees and inspire honesty, creativity,commitment and personal fulfillment (Krishnakumar and Neck, 2002). According to Bhatti et al., (2015) islamic spirituality (IS) can provide a purposeful solution to manage the issue ofWDBs faced by organization.

\section{Problem Statement}

According to Saeed et al., (2014), there are very limited studies on the effect of human resource management (HRM)practices on deviant workplace behavior. It is very surprising that such important aspect is neglected becauseone of the most important asset of the organization are human resources. Employees in the organization able to decide the competitiveness of theorganization to a great extent as they are extremely rare, matchless, extraordinary and 
precious resources.Due to limited researches done on the effect of Human resource management practices on workplace deviant behavior, the general researches on job performance give theoretical possibility in hypothesizing the impact of HR practices on deviant behavior at work. As literature on negative work outcome e.g. employee turnover and absenteeism is illustrated, it can be possible that there is a linkage between human resource practices and deviant behavior at work.

Research has pointed to workplace deviance as a prevalent and costly problematic for organizations. Examples of DWBs include coming in late to work without giving notice and putting little effort into work. Coffin (2003) reported that 75\% of employees have taken property from their employers at least once, and Case (2000) stated that $95 \%$ of all organizations experience employee theft. Similarly, other studies have documented not only the financial effect of DWBs, but also their negative social and psychological effects within organizations (Hollinger \& Clark, 1982, 1983; Murphy, 1993; Robinson \& Greenberg, 1998). One survey found that $42 \%$ of women reported being harassed at work (Gruber, 1990).

From Malaysia context, since the 1980s, there was a major change in the government's effort to improve the quality of public services efficiency with the implementation of a new service called Public Management Reform (Siddique, 2006). This was meant to strengthen professionalism, efficiency and high work ethic among the civil servants (Mohd Koharuddin et al., 2012). One of the challenges needs to be addressed is the issues relevant to the members in every organization. Each organization is very much dependent on its members and this is likely that the organization is very much related to the behaviour and attitude of its own members. In the context of employment, behaviour is divided into two, i.e. positive and negative behaviour. An organization needs positive behaviour from every employee to ensure efficient work and increased productivity (Robins \& Judge, 2009). Nevertheless, this positive behaviour can change into negative behaviour if an organization does not provide job requirements which in the end leads to unproductive work from the employees. Negative behaviour may happen in three ways among which are refusal of the employees to work, being too selective in their work, being ignorance and refuse to work. These individuals will find ways and excuses from doing their work (Robins \& Judge, 2009). Being selective in work has existed since ancient civilization. This kind of behaviour towards employment is very much related to a member's attitude and work ethic. Work ignorance can happen in different ways such as do not like to work, delay, absent, too much of rest, influence other members not to work hard and many others (Robins \& Judge, 2009). It is obvious that positive behaviour refers to the criteria an individual has, i.e. productive behaviour, whilst negative behaviour may produce an unproductive individual who may be unproductive at work.

To date, the Malaysian public service has staff strength of 1.6 million employees, covering 28 schemes of service. In 2010-2012, the Public Complaints Bureau (PCB) (http://www.bpa.jpm .my/) registered a high number of complaints filled by the public regarding delays in the actions taken and services provided by the employees of public organizations. Newspaper headlines also highlighted complaints from the public regarding their dissatisfaction with the services provided suggesting that service quality is low and does not match customer expectations. The police, 
hospitals, the National Registration Department and the Immigration Department were among the 10 government departments or agencies which received the most number of complaints.

\section{Research Objectives}

This study aims to look into the effects of human resource practices, islamic spirituality on Deviant Work Behavior (DWBs).The major objectives of this study are:

a. to examine the relationship between human resource practices and Deviant Work Behavior (DWBs).

b. to examine the moderating effects on the relationship between human resource practices and Deviant Work Behavior (DWBs)

\section{Research Questions}

From the above-stated objectives of the research, the following research questioned are formulated:

a. How significant is the impact of human resource practicesonDeviant Work Behavior (DWBs)?

b. Does the Islamic spirituality influence on Deviant Work Behavior (DWBs)?

\section{Research Hypothesis}

$\mathrm{H} 1$ : $\quad$ Employment security of employees negatively correlates with deviant workplace behavior

H2: Job description negatively correlates with deviant workplace behavior

H3: There is a negative relationship between internal career opportunities and Deviant work place behavior

$\mathrm{H} 4$ : There is a negative relationship between Result-oriented appraisal and Deviant work place

\section{The significance of The Study}

This research is expected to conttribute theoretically and practically to knowledge in the academic field.

a) Add to the body of the knowledge

b) To the Immigration Department of Malaysia

c) Add to existing literature

\section{Scope of the Study}

The study focus on the relationship between human resource practices, islamic spirituality on Deviant Work Behavior (DWBs) among employees in Immigration department in Malaysia.

\section{Literature Review}

\section{Human Resource Practices}

HR practices are a set of planned strategies and policies implemented by an organization to ensure organization's human capital efficiently and effectively contributes to the achievement of organizational objectives (Mondy and Noe, 2005). Robbins and Judge (2010) claimed that human 
resource practices are one of the factors in the organization that could shape and determine employee responses at work and potentially have influence on Deviant Work Behavior (DWBs). Human resources practices have a capability in determining employee behavior and attitude at workplace.Human Resource Practices has been considered as a critical factor that affects employees' level of commitment, intentions to leave and amount of job satisfaction (Lee and Heard, 2000). He added that Human Resource practices impact their attitudes and behaviors of employees.

According to Saeed et al. (2014), different organizational factors have been investigated that supposed to influence deviant workplace behavior. To name a few, these factors include organizational control, organizational justice and organizational climate. Generally, these studies seems to point out that lack of justice reflect unfavorable work environment and maybe influence employees to engage in deviant workplace behavior. One of the most vital organizational factor that supposed to have capability in determining employee behavior and attitude at work is human resource (HR) practices. Number of researchers agrees that managing the pool of human resource is called $\mathrm{Hr}$ practices. Moreover to make sure that resources are used for the accomplishment of organizational goals.

\section{Deviant Work Behavior (DWBs)}

In the literature, employee deviance is referred to by many names including: employee misconduct, counterproductive workplace behavior, and organizational misconduct (Vardi \& Weitz, 2004).A number of researchers have tried to build up develop a comprehensive classification of deviant behaviour, however they have just centered on the deviance that affects the well-beings of organization. In view of these frameworks, Robinson and Bennett (1995) has introduced a typology of workplace deviance, which also examining the cost towards individual personnel brought by the interpersonal deviance (Bennett \& Robinson, 2000; Muafi, 2011; Robinson \& Bennett, 1995). The framework introduced by Robinson and Bennett (1995) comprises of two dimensions, which is interpersonal deviance and organizational deviance. Interpersonal deviance consisted of the deviant behaviour that aims towards other individual worker, such as blaming, bullying, and gossiping about others. In addition, organizational deviance involves destructive behaviour of individual towards the organization, such as sabotage, leave early, or work theft (Bennett \& Robinson, 2000; Robinson, 2008).

Thus, workplace deviant behaviour is defined as the employees' personal voluntary effort and behaviour that go against and violate the organizational norms which might threaten the wellbeings of individual colleague, productivity of organization, or both (Robinson, 2008; Robinson \& Bennett, 1995). Broad number of researches has affirmed workplace deviance is adverse, offensive and disruptive behaviour that has negative relationship towards individual personnel and organizational well-being (Dunlop \& Lee, 2004; Jelinek, 2012; Robinson, 2008). In fact, workplace deviance serve as the challenges for organizational growth (Lawrence \& Robinson, 2007). Furthermore, workplace bullying can eventually leads to lower level of morale and selfesteem, higher level of stress and depression, and profound impact in psychological health of victim employee (de Gouda, Van Vuuren, \& Crafford, 2005; Duffy \& Sperry, 2007). In the worst situation, organization might need to take responsibility and face the possible lawsuit regarding 
the workplace aggression, even though these behaviours were aimed at individual workers (Speedy, 2006).

Multidimensional delineations have identified facets of DWBs. In two main dimensions, minor versus serious and interpersonal versus organizational, DWBs fall into four distinct categories: production deviance, property deviance, politi-cal deviance, and personal aggression (Robinson \& Bennett, 1995). Production deviance would include leaving early, taking excessive breaks, and intentionally working slowly. In a later study, Bennett and Robinson (2000) divided DWBs into two types: behavior that is directly harmful to the organization as a whole (DWBOs), and behavior that is more concerned with harming individuals within the organization (DWBIs). Examples of DWBIs include gossiping about and blaming coworkers, whereas coming in late to work without giving notice and putting little effort into work are examples of DWBOs. Table 1 shows the typology deviant workplace behavior.

\section{Islamic Spirituality}

Weaver and Agle (2002) proved that religiosity has an influence both on human attitudes and behaviors. It is one of the factors that significantly influence people's values, ethical judgments, ethical and social responsibilities (Ibrahim et al., 2008). Religiosity in general has a positive impact on ethical attitudes. Furthermore, it provides an important basis for social integration and the prevention of deviant behaviors (Stack and Kposowa, 2006). Practicing religious beliefs or attending religious activities are also positively related to the ethical attitudes (Phau and Kea, 2007).

Kazmi (2004) suggested that the field ofmanagement is growing progressively with increased interest in religion andspirituality. However, research on the role of IS and its contribution to the overall growth of an organization is inadequate (Kamil et al., 2011). In the similar vein, the concept of social responsibility has been studied mostly at the corporate level, wherein a corporation is treated as a social citizen (Appelbaum et al., 2007; Kolodinsky et al., 2010). Because an organization is a microcosm of a society, the behavior of its members will affect not only the organization but also the society as a whole. Thus, the present study embarks on social responsibility from an individual perspective and proposes IS and Islamic social responsibility (ISR) as two plausible motivators that can help reduce WD. It examines the relationship between predictors IS and ISR and criterion WD in the manufacturing and services industry in Pakistan.

\section{Theories on HRM Practices and Deviant Work Behavior (DWBs).}

Several theories were important in this research. The theory from Guest (1997) model will be the umbrella theory to underpin this stuidy. The starting point linking HRM and performance, according to Guest (1997) is assumption that improved performance is achieved through the people in the organization. The essence of the model is based on several proposals. First, the role of external context and strategy is acknowledged. Second, Guest (1997) uses the expectancy theory as a possible basis for developing a more coherent rationale about HRM and performance link. The theory proposes that performance at individual level depends on high motivation, possession of the necessary skills and abilities and an appropriate role and understanding of that role. This conclusion is a cause to choose such HRM practices that lead to high employee 
commitment, high quality staff and highly flexible staff. Third, the model encompasses the list of HRM practices that help to achieve appropriate HRM outcomes. Fourth, the model separates behaviour, performance and financial outcomes.

Theory that explain work deviant behavior is from Robinson and Bennett (1995). This theory applied the multidimensional scaling procedure to derive the typology of workplace deviance. They divided deviant workplace behaviors into two dimensions: One was labeled as the organizational-interpersonal dimension. The dimension differs from deviant behavior targeted at the organization (e.g., stealing equipment) to deviant behavior primarily aimed at a member of the organization (e.g., spreading rumor). This dimension mainly focuses on the target of the deviant behavior. The second dimension demonstrated the severity of the deviant behavior. In this dimension, deviant behavior varied from minor forms of deviance (e.g., blaming fellow employees) to serious forms of deviant behavior (e.g., verbal abuse)

\section{Conceptual Framework}

From the reviewed literature, job description, employment security, result-oriented appraisal and internal career opportunity been adopted as independent variables of the study and work deviance behavior as the dependent variable. Islamic spirituality as a moderator in this study.

\section{Measures}

All constructs were measured using self-reports, and all items were accessed using a seven-point Likert-type scale (i.e. $1_{\text {_ }}$ never, $7_{\text {_ }}$ always).

\section{Deviant Workplace Behavior}

A 21-item scale was adopted from Bennett and Robinson (2000). Example items include "Taken anadditional or a longer break than is acceptable at your workplace", "Come in late to workwithout permission", "Played a mean prank on someone at work" and "Acted rudelytowards someone at work".

\section{HR Practices}

A 23 items scale adopted by Delery(1996). All items employed a fivepoint scale ranging from ' 1 ' "strongly disagree" to ' 5 ' "strongly agree". Participants were asked to indicate their level of agreement (or disagreement) with regards to the human resource practices in their organization on items such as "Employees in this job will normally go through training programs every few years," "Performance appraisals are based on objective, quantifiable results" and "Job security is almost guaranteed to employees in this job."

\section{Islamic Spirituality (IS)}

IS and ISR weremeasured by 15-items, developed by Kamil (2012), Example items include "Isupplicate Allah whenever I face difficulty in my work", "Whenever I make a mistake lask Allah's forgiveness", "I treatmyco-workers equally" and "I helpmyco-workers whoneed help". 


\section{Organization of the Proposal}

The preceding sections have elaborated on the background of the study, its problems and objectives. Subsequently, the significance and the scope of the study are outlined. The second chapter presents literature review of human resource practices, variables related to the studyand theoretical framework of study and hypotheses development. The third chapter focuses on the methodology used in the study with regard to the sample, research instruments, data collection procedures and the type of analysis employed.

\section{Conclusion}

The researchers have pointed out various aspects pertaining to HRM performance relationship, a hotly debated topic in HRM literature. Notably the paper has tried to break down the Performance variable to several measures that fall into two broad categories, that is financial and non financial measures. Although most researches dwell on financial performance, there is a need for a balanced approach that considers non financial measures dwelling on HRM effectiveness. Additionally, several theories and models have been considered. They need to be included when investigating this relationship as part of the theoretical framework. Even with the shift to studying HRM systems and their relationship with firms' performance as opposed to individual HRM practices, there is a need to group these practices in broad areas HR in which they belong. This approach makes it possible to explain clearly the contribution of a certain broad $\mathrm{HR}$ area to performance without losing the larger picture. More research investigating this issue needs to be done in other contexts especially in Africa, and also in non manufacturing firms as well as charitable organizations. The future findings of this study is needed to help implement specific measures to reduce issues related to counterproductive work behaviour among civil servants. Wrongdoings at work do not only affect an organization but also affect the growth of the country as a whole. The involvement of members and the organization management is essential in instilling a sense of belonging to the organization and improvement of working ethic can counterproductive work behaviour in an organization. Proper develop of human resource practices will ensure that an employee will provide just and perfect services to the public. High and strong work ethic can prevent civil servants from any misconduct in services. 
INTERNATIONAL JOURNAL OF ACADEMIC RESEARCH IN BUSINESS AND SOCIAL SCIENCES

Vol. 8, No. 11, Nov, 2018, E-ISSN: 2222-6990 @ 2018 HRMARS

\section{References}

1. Chirasha, V. and Mahapa, M. (2012), "An analysis of the causes and impact of deviant behavior inthe workplace: the case of secretaries in state universities", Emerging Trends in Economicsand Management Sciences (JETEMS), Vol. 3 No. 5, pp. 415-421.

2. De Gouda, C., Van Vuuren, L., \& Crafford, A. (2005).Towards a Typology of gossip in the workplace.SA Journal of Human Resource Management, 3(2).

3. Duffy, M., \& Sperry, L. (2007). Workplace mobbing: Individual and family health consequences. The Family Journal, 15(4), 398-404.

4. Dunlop, P. D., \& Lee, K. (2004). Workplace deviance, organizational citizenship behavior, and business unit performance: The bad apples do spoil the whole barrel. Journal of Organizational Behavior, 25(1), 67-80.

5. Eisler, R. and Montouori, A. (2003), The Human Side of Spirituality, M. E. Sharp, New York, NY.

6. Fry, L.W. (2003), "Toward a theory of spiritual leadership", The Leadership Quarterly, Vol. 14 No. 6, pp. 693-727.

7. Jelinek, K. (2012). Deviance at RKGA LLP.Issues in Accounting Education, 27(2), 475-491.

8. Krishnakumar, S. and Neck, C.P. (2002), "The 'what', "why" and "how" of spirituality in the workplace", Journal of Managerial Psychology, Vol. 17 No. 3, pp. 153-164.

9. Lawrence, T. B., \& Robinson, S. L. (2007).Ain't misbehavin: Workplace deviance as organizational resistance.Journal of Management, 33(3), 378-394.

10. Mat, N. and Naser, N.M. (2012), "Workplace spatiality and counterproductive work behaviour (CWB): a Malaysian perspective", paper presented at the 3rd International Conference on Business and Economic Research Proceeding, Bandung.

11. Meiners, C. (2005). Employee fraud: Detecting and eliminating the unintentional perk. Risk Management, 52, 50-54.

12. R.J. Bennett, S.L. Robinson (2000). Development of a measure of workplace deviance, Journal of Applied Psychology, 85, pp. 349-360, 10.1037/0021-9010.85.3.349

13. Robinson, S. L. (2008). Dysfunctional workplace behavior. The Sage handbook of organizational behavior, 1, 141-159.

14. Robinson, S. L., \& Bennett, R. J. (1995). A typology of deviant workplace behaviors: A multidimensional scaling study. Academy of management journal, 38(2), 555-572.

15. Reave, L. (2005), "Spiritual values and practices related to leadership effectiveness", TheLeadership Quarterly, Vol. 16 No. 5, pp. 655-687.

16. Sulaiman, M. and Bhatti, O.K. (2013b), "Workplace deviance and spirituality in Muslim organizations", Asian Social Science, Vol. 9 No. 10, pp. 237-246.

17. Bhatti, K.O. (2015), "Impact of Taqwa (Islamic Piety) on Workplace Deviance", PhD in BusinessThesis, International Islamic University Kuala Lumpur.

18. Siddiquee, N, A. (2006). Public management reform in Malaysia: Recent initiatives and experiences. International Journal of public Sector Management, 19(4) 25-32.

19. Sackett, P. R., DeVore, C. J. (2001). Counterproductive behaviors at work. In Anderson N., Ones D. S., Sinangil H. K., Viswesvaran C. (Eds.), Handbook of industrial, work, and organizational psychology: Vol. 1, 145-164. London: Sage. 
INTERNATIONAL JOURNAL OF ACADEMIC RESEARCH IN BUSINESS AND SOCIAL SCIENCES

Vol. 8, No. 11, Nov, 2018, E-ISSN: 2222-6990 @ 2018 HRMARS

20. Spector, P. E., Fox S., Penney, L. M., Bruursema, K., Goh A., Kessler, S. (2006). The dimensionality of counterproductivity: Are all counterproductive behaviors created equal? Journal of Vocational Behavior, 68: 446-460.

21. Robbins, S.P. \& Judge, T.A. (2009). Organization Behavior (13th ed). New Jersey: Pearson Prentice Hall.

22. Adler, G., Schminke, M., Noel, T. \&Kuenzi, M. (2008). Employee reactions to Internet monitoring: The moderating role of ethical orientation. Journal of Business Ethics, 80, 481-498.

23. Business Wire. (2000). A landmark survey by telemate.net software shows that $83 \%$ of companies are concerned with the problem of internet abuse. July 31.

24. Block, W. (2001). Cyberslacking business ethics and managerial economics. Journal of Business Ethics,33, 225-231.

25. Case, C.J. \& Young, K.S. (2002a). Behavioral factors affecting Internet abuse in the workplace-an empirical investigation. Proceedings of the Third Annual Workshop on $\mathrm{HCl}$ Research in MIS, Washington, D.C., December 10-11, 2004.

26. Chen, J., Chen, C. \& Yang, H. (2008). An empirical evaluation of key factors contributing to Internet abuse in the workplace. Industrial Management \& Data,108, 87-106.

27. Debt Cubed, (2006). Are your internet costs going through the roof? Debt Cubed, 21 (1), 10.

28. Fox, A., 2007. Caught in the web. HR Magazine, Society for Human Resource, 35-39.

29. Richards, J. (2010). The employee and the Internet age: A reflection, map and research Agenda. International Labour Process Conference, Rutgers University, New Jersey, USA:

30. Lim, V. K.G., Teo, T. S. H \& Loo G.K. (2002) How do I loaf here? Let me count the ways. Communications of the ACM, 45 (1), $66-70$.

31. Lim, V. K. G. (2002). The IT way of loafing on the job: cyberloafing, neutralizing and organizational justice. Journal of Organizational Behavior, 23(5), 675-694.

32. Srinivasan, V. (2008). The "Darth" side of technology use: Cyberdeviant workplace behaviors, Unpublished Thesis.

33. Young, K. S., \& Case, C. J. (2004). Internet abuse in the workplace: New trends in risk management.CyberPsychology\&Behavior, 7(1), 105-111.

34. Rashid Saeed ,MiznaRab, Nawaz Lodhi, Atif Ali Gill, Anam Amin, Simra ,Amber Iqbal(2014). Impact of Human Resource Practices on Deviant Workplace Behavior: A Study on Banking Sector Employees . Journal of Basic and Applied Scientific Research4(2)81-86,

35. Wen, H. \& Lin, B. (1998). Internet and employee productivity. Management Decision, 36, 395-398

36. ZoghbiManrique de Lara, P. (2011). Reconsidering the boundaries of the cyberloafing activity: The case of a university. Behaviour \& Information Technology, 37 (1), 1-1.

37. Zuckerman, M., Silberman, J., \& Judith A. (2013). The Relation Between Intelligence and Religiosity: A Meta-Analysis and Some Proposed Explanations . Personality and Social Psychology Review 17(4) 325-354 013 by the Society for Personality and Social Psychology, Inc. 